\title{
Correction to: Index selection can improve the selection efficiency in a rice recurrent selection population
}

\author{
Paulo Henrique Ramos Guimarães (1) Patrícia Guimarães Santos Melo • \\ Antônio Carlos Centeno Cordeiro • Paula Pereira Torga • Paulo Hideo Nakano Rangel • \\ Adriano Pereira de Castro
}

Published online: 2 June 2021

(C) The Author(s), under exclusive licence to Springer Nature B.V. 2021

Correction to: Euphytica (2021) 217:95

https://doi.org/10.1007/s10681-021-02819-7

In the above mentioned publication, the affiliations of the last 4 authors were interchanged. The original article has been corrected and the proper display of the authors' affiliations is also provided here.

Publisher's Note Springer Nature remains neutral with regard to jurisdictional claims in published maps and institutional affiliations.

The original article can be found online at https:// doi.org/10.1007/s10681-021-02819-7.

P. H. Ramos Guimarães $(\bowtie)$ · P. Guimarães Santos Melo Universidade Federal de Goiás, Rodovia GO-462, km 0, Campus Samambaia, Goiânia, GO 74001-970, Brazil e-mail: paulohenriquerg@ @otmail.com

A. C. Centeno Cordeiro

Embrapa Roraima, Rodovia BR-174 km 8, Roraima, RR 69301-970, Brazil

P. Pereira Torga · P. H. Nakano Rangel ·

A. Pereira de Castro

Embrapa Arroz e Feijão, Santo Antônio de Goiás,

Rodovia GO-462, km 12, Santo Antônio de Goiás,

GO 75375-000, Brazil 